\title{
Unusual manifestations of brucellosis
}

\author{
Onur Kaya, Kemal Avşar, Füsun Zeynep Akçam
}

Depertment of Clinical Microbiology and Infections Diseases, Suleyman Demirel University School of Medicine, Isparta, Turkey

Submitted: 2 September 2010

Accepted: 6 November 2010

Arch Med Sci 2011; 7, 1: 173-175

DOI: 10.5114/aoms.2011.20627

Copyright (c) 2011 Termedia \& Banach

\section{Abstract}

Brucellosis is an important public health problem in the Mediterranean countries, including our country. Furthermore, because of different symptoms and clinical findings, the disease could be confused with several other diseases. In this article, three unusual findings of brucellosis are presented: pancytopenia, endocarditis and meningitis.

Key words: brucellosis, endocarditis, meningitis, pancytopenia.

\section{Introduction}

Brucellosis remains the commonest zoonotic disease worldwide with more than 500,000 new cases annually [1]. The symptoms of brucellosis are non-specific; therefore, it may be difficult to diagnose [2]. The disease may be overlooked and misdiagnosed because of atypical clinical manifestations. The purpose of this paper is to emphasize atypical presentations of brucellosis.

\section{Case 1}

A 26-year-old female presented with fever, night sweats, headache and malaise for one week. The patient had been initially presented to a general practitioner with the same symptoms five days before admission and given antibiotic treatment (second-generation cephalosporin) and paracetamol. On admission her vital signs were as follows: body temperature: $38.5^{\circ} \mathrm{C}$, arterial blood pressure: $70 / 30 \mathrm{mmHg}$, heart rate: $118 / \mathrm{min}$ and respiration rate: $14 / \mathrm{min}$. Physical examination revealed hepatosplenomegaly. Laboratory tests showed haemoglobin: $10.2 \mathrm{~g} / \mathrm{dl}$, white blood cells: $2700 / \mathrm{mm}^{3}$ with polymorphs $35 \%$, lymphocytes $52 \%$, monocytes $10 \%$ and eosinophils $3 \%$. The platelet count was $37 \times 10^{9} /$. Erythrocyte sedimentation rate (ESR) was $32 \mathrm{~mm}$ in the first hour. C-reactive protein (CRP) was $98 \mathrm{mg} / \mathrm{dl}$. Brucella standard tube agglutination (STA) test was negative (or 1/80 titre). Grubel-Widal and monospot tests were negative. Blood and urine cultures were negative; three blood cultures for Brucella were also negative after 14 days of incubation. On day 6., Brucella spp. were isolated from bone marrow culture. Clinical and haematological findings improved with the treatment of brucellosis with streptomycin ( $1 \mathrm{~g} / \mathrm{d}$ i.m.) and doxycycline $(2 \times 100 \mathrm{mg} / \mathrm{d}$ p.o.).

\section{Case 2}

A 50-year-old male presented with malaise, fever, cough, night sweats for ten days. On admission his vital signs were as follows: body

\author{
Corresponding author: \\ Onur Kaya MD, PhD \\ Depertment of Clinical \\ Microbiology and Infections \\ Diseases \\ Suleyman Demirel University \\ School of Medicine \\ 32260 Isparta, Turkey \\ Phone: + 902462119325 \\ E-mail: \\ onurkaya@med.sdu.edu.tr
}


temperature: $38.0^{\circ} \mathrm{C}$, arterial blood pressure: $110 / 70 \mathrm{mmHg}$, heart rate: $86 / \mathrm{min}$, respiration rate 20/min. Physical examination revealed cardiac murmur and hepatosplenomegaly. Laboratory tests showed haemoglobin: $11.1 \mathrm{~g} / \mathrm{dl}$, white blood cells: $15600 / \mathrm{mm}^{3}$, platelets: $406 \times 10^{9} / \mathrm{mm}^{3}$, CRP: $85 \mathrm{mg} / \mathrm{dl}, \mathrm{ESR}: 44 \mathrm{~mm} / \mathrm{h}, \mathrm{AST}: 75 \mathrm{U} / \mathrm{L}$ (N: 0-31), ALT: $21 \mathrm{U} / \mathrm{L}$ (N: 0-34), rheumatoid factor: 148 (N: 0-15) IU/ml. Echocardiogram showed vegetation of $15 \times 13 \mathrm{~mm}$ on posterior mitral leaflet. STA was positive at a titre of $1 / 640$. On day 4 ., Brucella spp. were isolated from blood culture. The patient was put on treatment with doxycycline $(200 \mathrm{mg} / \mathrm{d}$ p.o.), rifampicin $(1 \times 600 \mathrm{mg} / \mathrm{d}$ p.o.) and ceftriaxone $(2 \times 1 \mathrm{~g} / \mathrm{d}$ i.v. $)$. The surgery was planned for endocarditis.

\section{Case 3}

A 41-year-old male presented with fever and confusion. On admission his vital signs were as follows: body temperature: $38.5^{\circ} \mathrm{C}$, arterial blood pressure: $130 / 70 \mathrm{mmHg}$, heart rate: $87 / \mathrm{min}$ and respiration rate: $18 / \mathrm{min}$. On physical examination, he had neck stiffness and confusion. Kernig's and
Brudzenski's signs were negative and focal neurological signs were not detected. Blood parameters revealed the following values: haemoglobin: $14 \mathrm{~g} / \mathrm{dl}$, white blood cells: 10600/ $\mathrm{mm}^{3}$ (polymorphs $55 \%$, lymphocytes $24 \%$, monocytes $18 \%$, eosinophils $3 \%$ ); platelets: $223 \times 10^{9} / \mathrm{mm}^{3}$. Serum electrolytes, creatinine levels and liver parameters were within normal limits. A lumbar puncture performed on admission showed 450 leucocytes $/ \mathrm{mm}^{3}$. The Gram staining of cerebrospinal fluid (CSF) was negative. Glucorrhachia/glycaemia was $11 / 85 \mathrm{mg} / \mathrm{dl}$ and the protein concentration was $271 \mathrm{mg} / \mathrm{dl}$. The STA titre in CSF was $1 / 10$. A presumptive diagnosis of bacterial meningitis was established. Therapy with intravenous ceftriaxone $(2 \times 2 \mathrm{~g} / \mathrm{d})$ was initiated. On day 8., Brucella spp. were isolated from CSF culture. Doxycycline $(200 \mathrm{mg} / \mathrm{d})$ and rifampicin $(1 \times 600 \mathrm{mg} / \mathrm{d})$ were added to the treatment. Symptoms regressed with the treatment.

\section{Discussion}

Brucellosis is a common zoonotic disease in endemic areas such as Turkey. It is a disseminated

Table I. Characteristics of the patients

\begin{tabular}{|c|c|c|c|}
\hline & Case 1 & Case 2 & Case 3 \\
\hline Age/Sex & $26 / F$ & $50 / M$ & $41 / M$ \\
\hline Symptoms & $\begin{array}{l}\text { Fever, night sweats, } \\
\text { headache, malaise }\end{array}$ & $\begin{array}{c}\text { Fever, cough, night sweats, } \\
\text { malaise }\end{array}$ & Fever, confusion \\
\hline Pathological findings & $\begin{array}{l}\text { Fever, hypotension, } \\
\text { hepatosplenomegaly }\end{array}$ & $\begin{array}{l}\text { Fever, cardiac murmur, } \\
\text { hepatosplenomegaly }\end{array}$ & $\begin{array}{l}\text { Fever, neck stiffness, } \\
\text { confusion }\end{array}$ \\
\hline \multicolumn{4}{|l|}{ Laboratory findings } \\
\hline Haemoglobin [g/dl] & 10.2 & 11.1 & 14 \\
\hline White blood cells & $2700 / \mathrm{mm}^{3}$ & $15600 / \mathrm{mm}^{3}$ & $10600 / \mathrm{mm}^{3}$ \\
\hline Platelet & $37 \times 10^{9} / \mathrm{mm}^{3}$ & $406 \times 10^{9} / \mathrm{mm}^{3}$ & $223 \times 10^{9} / \mathrm{mm}^{3}$ \\
\hline CRP $[\mathrm{mg} / \mathrm{dl}]$ & 98 & 85 & 3.2 \\
\hline $\mathrm{ESR}[\mathrm{mm} / \mathrm{h}]$ & 32 & 44 & \\
\hline $\mathrm{RF}[\mathrm{IU} / \mathrm{ml}]$ & & 148 & \\
\hline STA & $1 / 80$ & $1 / 640$ & 1/10 (in CSF) \\
\hline CSF & & & $\begin{array}{c}450 \text { leucocytes } / \mathrm{mm}^{3} \\
\text { Glucorrhachia/glycaemia: } \\
\text { 11/85 mg/dl } \\
\text { Protein: } 271 \mathrm{mg} / \mathrm{dl}\end{array}$ \\
\hline Echocardiogram & & $\begin{array}{l}\text { Vegetation of } 15 \times 13 \mathrm{~mm} \\
\text { on posterior mitral leaflet }\end{array}$ & \\
\hline Culture & $\begin{array}{l}\text { Brucella spp. were isolated } \\
\text { from bone marrow culture }\end{array}$ & $\begin{array}{l}\text { Brucella spp. were isolated } \\
\text { from blood culture }\end{array}$ & $\begin{array}{l}\text { Brucella spp. were isolated } \\
\text { from CSF culture }\end{array}$ \\
\hline Treatment & $\begin{array}{l}\text { Doxycycline + } \\
\text { streptomycin }\end{array}$ & $\begin{array}{l}\text { Doxycycline + rifampicin } \\
+ \text { ceftriaxone }\end{array}$ & $\begin{array}{c}\text { Doxycycline + } \\
\text { rifampicin + ceftriaxone }\end{array}$ \\
\hline
\end{tabular}

F-female, M-male, CRP-C-reactive protein, ESR - erythrocyte sedimentation rate, STA - standard tube agglutination, RF-rheumatoid factor, CSF - cerebrospinal fluid 
infection that may present with a broad spectrum of clinical manifestations; therefore, it may be difficult to diagnose [2].

The haematological abnormalities (leucopenia, anemia, thrombocytopenia) are common in brucellosis but pancytopenia is rare. The pathogenesis of pancytopenia in brucellosis has not been clearly understood, but it seems to be multifactorial. Several possible mechanisms have been suggested for pancytopenia caused by brucellosis, such as hemophagocytosis, hypersplenism, bone marrow granulomas, bone marrow hypoplasia, and immune destruction [3]. In presented case 1, pancytopenia may be caused by hypersplenism. On the other hand, blood culture is the gold standard in the diagnosis of brucellosis. The sensitivity of blood culture depends on several factors such as previous use of antibiotics and phase of the disease. Bone marrow cultures may provide higher sensitivity, yield faster culture times, and may be superior to blood cultures when evaluating patients with previous antibiotic use $[4,5]$. In our case, blood cultures were negative probably due to the used antibiotic.

Endocarditis occurs in less than $2 \%$ of cases, but it accounts for the majority of brucellosis-related deaths $[2,6]$. Brucella endocarditis may develop on valves, previously damaged by rheumatic fever or congenitally malformed, but may also occur on previously normal valves. The clinical features are distinguishable from those of endocarditis caused by other organisms. The aortic valve is the most commonly affected cardiac valve $[2,6]$. In our case 2 , the mitral valve was affected. The diagnosis of endocarditis was made in accordance with Duke's criteria. Brucellosis may lead to complications that affect different organs and systems; among them endocarditis is a rare but serious complication.

Neurologic manifestations of brucellosis occur in $5 \%$ of patients [4]. Among the clinical manifestations, meningitis has been the most frequent presentation in clinical series and usually presents in an acute or chronic form. However, it has been noted that $<40 \%$ of the patients with brucellar meningitis exhibit meningeal signs. In our case, we observed neck stiffness. The diagnosis of brucellar meningitis depends on the demonstration of meningeal inflammation, abnormal CSF findings, and direct or indirect evidence of Brucella in the CSF $[2,7]$. Cerebrospinal fluid analysis reveals a lymphocytic pleocytosis, elevated protein content, and low to normal glucose levels. Gram stains are usually negative and cultures are positive in less than one quarter of the cases; however, the diagnosis is based on the presence of specific antibodies in the cerebrospinal fluid [2, 4]. In our case, the diagnosis was made by microorganism isolation at the CSF and the antibodies detection in the CSF.
In conclusion, brucellosis is an important health problem especially in endemic areas. It may mimic many diseases (infectious or non-infectious). In patients living in endemic regions, considering brucellosis in differential diagnosis may lead to early diagnosis and treatment, and may decrease the complications.

\section{References}

1. Pappas G, Papadimitriou P, Akritidis N, Christou L, Tsianos EV. The new global map of human brucellosis. Lancet Infect Dis 2006; 6: 91-9.

2. Sari I, Altuntas F, Hacioglu S, et al. A multicenter retrospective study defining the clinical and hematological manifestations of brucellosis and pancytopenia in a large series: Hematological malignancies, the unusual cause of pancytopenia in patients with brucellosis. Am J Hematol 2008; 83: 334-9.

3. Young EJ. Brucella species. In: Mandell GL, Bennett JE, Dolin R (eds). Principles and practice of infectious diseases. $7^{\text {th }}$ eds. Philadelphia Churchill Livingstone 2010. Vol II: 2921-5.

4. Buzgan T, Karahocagil MK, Irmak H, et al. Clinical manifestations and complications in 1028 cases of brucellosis: a retrospective evaluation and review of the literature. Int J Infect Dis 2010; 14: e469-78.

5. Araj GF. Update on laboratory diagnosis of human brucellosis. Int J Antimicrob Agents 2010; 36 (Suppl. 1): S12-7.

6. Inan MB, Eyileten ZB, Ozcinar E, et al. Clin Cardiol. Native valve Brucella endocarditis. 2010; 33: E20-E26.

7. Gul HC, Erdem H, Bek S. Overview of neurobrucellosis: a pooled analysis of 187 cases. Int J Infect Dis 2009; 13: e339-43. 